\title{
KIT ENZYME-LINKED IMMUNOSORBENT ASSAY UNTUK DETEKSI WSSV PADA UDANG
}

\author{
Mun Imah Madeali \& Nurhidayah \\ Balai Riset Perikanan Budidaya Air Payau \\ Jl. Makmur Dg. Sitakka No. 129, Maros 90512, Sulawesi Selatan \\ E-mail:imah_patologi@yahoo.com
}

(Naskah diterima: 21 Maret 2011; Disetujui publikasi: 1 April 2011)

\begin{abstract}
ABSTRAK
Komponen dasar yang penting dan menentukan keberhasilan pengendalian suatu penyakit dalam bidang perikanan adalah informasi tentang patogen secara dini, cepat, dan akurat, serta epidemi penyakit di lapangan. Teknik serologi, khususnya ELISA, merupakan salah satu teknik yang menjanjikan untuk keperluan tersebut, karena relatif mudah dan murah, serta berpeluang untuk digunakan secara langsung di lapangan. Telah dilakukan uji lapang terhadap perangkat Kit ELISA yang telah diproduksi oleh Balai Riset Perikanan Budidaya Air Payau. Hasil uji lapang menunjukkan bahwa Kit ELISA dapat digunakan untuk mendeteksi penyakit WSSV pada udang windu, dengan waktu \pm 3 jam untuk setiap kali pengujian mulai persiapan sampai pembacaan hasil uji. Hasil Kit ELISA lebih cepat dibandingkan dengan metode PCR yang memerlukan waktu 24 jam. Biaya yang diperlukan untuk mendeteksi satu sampel juga lebih ekonomis yaitu \pm Rp 35.000,- dibandingkan dengan PCR (Rp 150.000,-- Rp 300.000,-) per sampel.
\end{abstract}

KATA KUNCI: kit ELISA, deteksi, WSSV, udang

\section{ABSTRACT: Kit elisa for WSSV detection in shrimp. By: Mun Imah Madeali and Nurhidayah}

\begin{abstract}
One of the important basic components that determine the success of fish disease control is a sufficiently, accurately and rapidly available of information about the pathogenic organism as well as the epidemic distribution of the disease in the field. ELISA is one of serological technique for shrimp disease detection because it is relatively inexpensive and easy to be used directly to detect WSSV infection in the cultured tiger shrimp. It takes about three hours from shrimp sample preparation to the final result. This method is faster than using PCR method that takes about 24 hours. The cost for one sample detection using ELISA (Rp 35,000,-) which is relatively cheaper compared to PCR method (Rp 150,000,- - Rp 300,000,-).
\end{abstract}

KEYWORDS: ELISA kit, detection, WSSV, shrimp

\section{PENDAHULUAN}

Virus merupakan salah satu patogen yang dapat menimbulkan kerugian yang sangat besar pada budidaya ikan dan udang. Virus berukuran sangat kecil, bersifat parasit obligat yang menyerang, serta memperbanyak diri dalam jaringan tubuh inangnya. Deteksi cepat terhadap keberadaan virus ini sangat diperlukan untuk mencegah terjadinya penularan. WSSV merupakan salah satu jenis virus yang paling banyak menimbulkan kematian udang di tambak (Peng et al., 2001). Menurut Chang et al. (1998), WSSV dapat mengakibatkan mortalitas pada udang windu sebesar 100\% dalam waktu 2-7 hari. Pada udang yang terserang virus secara morfologi terdapat bintik putih. Berbagai teknik baru 
untuk deteksi virus maupun organisme patogen lainnya masih terus dikembangkan, hal ini dilakukan untuk mendapatkan alat diagnosis yang memiliki spesivisitas dan sensitivitas yang tinggi.

Enzyme-linked Immunosorbent Assay (ELISA) merupakan salah satu teknik serologi yang dapat digunakan untuk mendeteksi patogen secara efektif dan efisien (Halk \& De Boer, 1985). Teknik ELISA dan perangkat deteksinya menggunakan antibodi poliklonal (AbPo) maupun AbMo telah dikembangkan secara komersial untuk deteksi virus dan bakteri patogen tanaman (van Regenmortel, 1986). Teknik ELISA juga telah diadopsi di Indonesia, tetapi perangkatnya masih harus diimpor dengan harga mahal dan masih menggunakan AbPo (Machmud et al., 1999).

Penggunaan AbPo untuk uji ELISA memiliki beberapa kelemahan, sehingga sejak tahun 1975, teknologi produksi antibodi monoklonal $(A b M o)$ telah dikembangkan (Kohler \& Milsten, 1975; Gigerli \& Fries, 1983). AbMo telah diproduksi untuk berbagai patogen tanaman termasuk virus, fitoplasma, dan bakteri (McLaughlin \& Chen, 1990). Pada tahun 1975 Kohler \& Milsten dalam Jordan (1990a) memperkenalkan teknik pembiakan sel penghasil antibodi melalui fusi dengan sel mieloma, sehingga dapat menghasilkan antibodi yang homogen secara terus-menerus, bereaksi serologi yang spesifik serta memiliki ciri-ciri biokimia tertentu pula. Hibridisasi selsel limposit penghasil antibodi dengan sel miolema (malignant myeloma cells) menghasilkan sel-sel hibridoma yang menggabungkan sifat-sifat parental dan kemampuan menghasilkan (mensekresi) antibodi yang spesifik dan terus tumbuh berkembang biak. Kloning dan seleksi lebih lanjut sel-sel hibridoma memberi peluang diproduksinya AbMo dengan spesifisitas yang sama (identik) dan efektivitas sesuai dengan yang diinginkan terhadap epitop tertentu pada antigen yang digunakan untuk imunisasi (Jordan, 1990b). Akhir-akhir ini teknik produksi mAb telah diadopsi untuk produksi AbMo patogen tanaman. AbMo telah digunakan untuk mendeteksi dan mengidentifikasi patogen tumbuhan termasuk virus, fitoplasma, dan bakteri (McLaughlin \& Chen, 1990). Kelebihan teknik produksi AbMo dari teknik AbPo di antaranya (1) mampu menghasilkan antibodi dalam jumlah relatif tidak terbatas, (2) kemampuan melestarikan produksi Ab yang spesifik melalui penyimpanan kriogenik hibridoma untuk waktu tidak terbatas, (3) kemampuan memproduksi dan menyeleksi AbMo untuk hampir semua determinan antigenik meskipun antigen yang digunakan untuk imunisasi tidak murni atau merupakan campuran Jordan, 1990a \& 1990b; De Boer \& Schaad, 1990). Teknologi hibridoma untuk produksi AbMo telah diterapkan pada virology dan bakteriologi tumbuhan. Metodologi yang mencakup pembuatan galur sel (cell lines) yang menghasilkan AbMo secara permanen relatif sederhana, tetapi memerlukan tahapan yang panjang dan seringkali sulit (crucial). Keberhasilan produksi AbMo tidak hanya bergantung pada produksi galur sel hibridoma dalam jumlah banyak, tetapi juga pada keberhasilan imunisasi hewan donornya. Pengetahuan dan pengalaman dasar tentang kultur sel (termasuk pembuatan medium, pemeliharaan, dan penyimpanan galur sel), dan pengembangan teknik serologi yang relatif sederhana, cepat, dan akurat untuk mengkarakterisasi dan mengidentifikasi antibodi. Penyediaan dan karakterisasi AbMo untuk berbagai antigen tanaman dan patogen dapat dilakukan. Berbagai publikasi tentang teknik produksi AbMo dapat digunakan sebagai bahan acuan (Jordan, 1990a). Hibridoma merupakan sel yang mudah rusak, memerlukan pengamatan mikroskopik untuk mengetahui viabilitas dan laju pertumbuhannya. Persyaratan lain untuk produksi AbMo adalah antigen dan uji serologis yang digunakan untuk mengidentifikasi dan karakterisasi antibody hibridoma. Sistem uji yang digunakan sangat tergantung pada jenis antigen dan rencana penggunaan AbMo (Jordan, 1990a).

Antibodi monoklonal (AbMo) untuk keperluan diagnostik penyakit ikan telah dilaporkan van Regenmortel (1986) dan Adam et al. (1995) antara lain terhadap Renibacterium salmoninarium dan Mycobacterium spina. Antibodi tersebut merupakan probe antibody yang sangat spesifik, sehingga dapat digunakan sebagai perangkat imunodiagnostic yang ampuh dalam teknik diagnosis seperti ELISA, imunohistokimia, dan Imunofluorosense (Harlow \& Lane, 1988 dalam Adam, 1995).

Teknik ELISA dengan menggunakan AbMo diperoleh dari hasil penelitian yang sangat khusus, teknik ini disukai karena secara umum lebih sensitif, spesifik, efisien, dan efektif untuk menguji sampel dalam jumlah besar, 
lebih murah, serta cukup mudah pengerjaannya. Untuk mengembangkan teknik diagnostik ELISA ini diperlukan Antibodi Monoklonal yang merupakan reagens uji imunokimia karena spesivisitas dan reproduksibilitasnya dengan satu kelompok kemasan ke kelompok kemasan yang lain jauh lebih kecil daripada antiserum tradisional.

Laboratorium Patologi Balai Riset Perikanan Budidaya Air Payau sedang mengembangkan alat diagnostik untuk mendeteksi adanya WSSV pada udang yang metode pengembangannya mengikuti standar OIE (1996) dan para peneliti sebelumnya tentunya dengan modifikasi sesuai dengan kondisi dan kemampuan yang ada. Adanya perangkat Uji ELISA ini diharapkan deteksi virus WSSV lebih cepat guna mencegah terjadinya penularan pada budidaya udang di tambak. Setelah proses tahapan standarisasi sistem pengujian yang berfungsi untuk mengevaluasi tingkat sensitivitas, spesivitas, dan akurasi data yang dihasilkan telah diselesaikan pada tahun 2008 , kemudian pada tahun anggaran 2009 dibuat perangkat kit ELISA (Enzim Linked Immunosorbent Assay) yang relatif stabil dan akurat dalam pendeteksian WSSV pada udang, maka pada tahun 2010 dilakukan Evaluasi Lapangan Perangkat Kit ELISA dengan Antibodi Monoklonal untuk deteksi penyakit yang disebabkan oleh virus WSSV pada budidaya udang.

\section{BAHAN DAN METODE}

Riset ini dilakukan di Laboratorium Kesehatan Ikan dan Lingkungan Balai Riset Perikanan Budidaya Pantai, dan uji lapang di Kabupaten Pinrang dan Pangkep (Sulawesi Selatan).

Produksi AbMo dilakukan dengan teknologi hibridoma yaitu melalui imunisasi mencit balb/ $C$ yang berumur 8 minggu setiap dua minggu dengan antigen WSSV. Setelah 8 kali booster, sel limpa diambil dan dikawinkan (fusi) dengan sel mieloma SP2/0-Ag14, kemudian dikultur dalam mikro plate 96 sumur/lubang sebanyak $150 \mu \mathrm{L} /$ sumur dan diinkubasi dalam inkubator $\mathrm{CO}_{2}$ pada suhu $37^{\circ} \mathrm{C}$. Fusi sel dicek setiap hari untuk mengetahui ada tidaknya kontaminasi, dan setiap 4-5 hari diberi nutrien dengan cara mengganti sebagian medianya dengan media kloning yang mengandung Hypoxanthine Thymidine (HT). Sel hibrid yang telah diskrining dan diklon akan tumbuh dan berkembang. Banyaknya sel yang menyebar, menutupi dasar sumur merupakan penanda terbentuknya antibodi monoklonal yang selanjutnya dicek nilai kerapatan optikal (OD) nya dari sekresi yang dihasilkan. Sel hibridoma yang menghasilkan antibodi monoklonal akan memiliki nilai OD lebih tinggi daripada nilai OD kontrol positif. Sel ini selanjutnya dikloning dengan metode limiting dilution pada plate tissue culture 96 lubang dan diberi nutrien setelah 7 hari, serta dicek kembali kandungan antibodi monoklonalnya. Hibridoma yang positif mengandung WSSV selanjutnya diinjeksikan pada mencit berumur 6-8 minggu yang sebelumnya telah diinjeksikan pristine 0,5 mL/ekor selama 7-14 hari. Setelah 1-3 minggu mencit akan memproduksi AbMo berupa cairan asitis yang dapat dipanen secara berkala.

Kit ELISA diproduksi menggunakan multiwell plate dari bahan maxisorp di mana 1 unit Kit ELISA menggunakan microplate yang terdiri atas 8 lubang. Kedelapan lubang tersebut berisi 2 lubang kontrol positif, 2 lubang kontrol negatif, 2 lubang untuk sampel 1 dan 2 lubang sampel 2 (masing-masing 2 ulangan), penempatannya dapat dilihat pada Gambar 1 .

Prosedur dari teknik ELISA yang dikembangkan mengikuti prosedur OIE (1996), di mana tiap lubang dari multiwell plate diisi $100 \mu \mathrm{L}$ monoklonal antibodi WSSV dengan coating plate dalam Bicarbonat buffer $\mathrm{pH}$ 9,6 inkubasi semalam pada suhu $4^{\circ} \mathrm{C}$. Setelah inkubasi 24 jam, maka Kit ELISA ini dapat digunakan untuk deteksi. Dalam 1 (satu) set Kit ELISA terdiri atas 20 unit multiwell plate 8 lubang yang disertai dengan pencuci plate dan pereaksi berupa:

- Pencuci Phosfat Buffer Saline (PBST) pH 7,2 (Botol A)

- Mouse $\alpha$ P1PK (AbPo) yang telah diencerkan dengan ELISA diluent (1:1000) (Botol B)

- Larutan konyugat Goat $\alpha$ Mouse yang telah dirunut dengan enzim Horseradish peroxidase (HRPO dalam buffer tris-EDTA-salinetween yang mengandung Kasein 0,02\% $(w / v)$ (TEN-T-C) yang telah diencerkan dengan ELISA diluent, dengan pengenceran 1/4000 (Botol C)

- Subtrat 2,2-Azino-bis(3-ethyl-benzthiazoline-6-sulfonat (ABTS) (Botol D)

- Syringe volume $1 \mathrm{~mL}$ untuk mengambil hemolimp udang, tissue lembab untuk inkubasi, dan penuntun penggunaan kit ELISA 


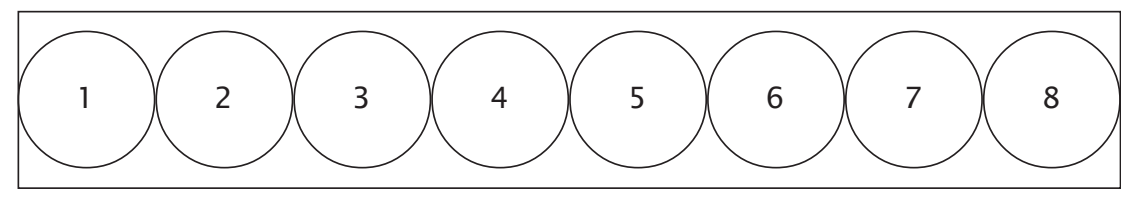

Keterangan:

Lubang $1 \& 2$ = Kontrol positif

Lubang $5 \& 6=$ Sampel B

Lubang $3 \& 4=$ Sampel $A$

Lubang $7 \& 8=$ Kontrol negatif

Gambar 1. Penempatan kontrol positif, negatif, dan sampel dalam mikroplate yang telah di-coating

Figure 1. The placement of the negative and positive controls, in the microplate which has been coated

Untuk mengetahui positif atau negatifnya suatu sampel terhadap WSSV, pengguna cukup melihat terjadinya perubahan warna pada plate, apabila terjadi perubahan warna dari bening ke hijau menandakan bahwa sampel yang diperiksa positif mengandung WSSV, sebaliknya apabila tidak terjadi perubahan warna artinya sampel tersebut tidak mengandung WSSV.

Selanjutnya mikroplate yang telah dicoating bersama pencuci dan pereaksinya di-packing menggunakan aluminium foil, kemudian diberi label. Untuk selanjutnya Kit ELISA siap digunakan.

Uji aplikasi Kit ELISA dilakukan di sentra budidaya udang di Kabupaten Pinrang dan Kabupaten Pangkep dengan melibatkan beberapa orang petani tambak untuk mendeteksi ada tidaknya serangan penyakit WSSV terhadap udang yang sedang dibudidayakan.

\section{HASIL DAN BAHASAN}

Telah diproduksi Kit ELISA (Gambar 2) untuk diagnosis penyakit WSSV pada udang windu. Kit ELISA yang telah diproduksi tersebut menggunakan multiwell plate dari bahan Maxisorp yang terdiri atas 8 lubang. Tiap lubang dari multiwell plate tersebut dilapisi (coating plate) dengan Antibodi Monoklonal (AbMo) WSSV dalam Bicarbonat buffer pH 9,6 yang telah diproduksi sebelumnya.

Proses uji ELISA di lapangan adalah sebagai berikut:

1. Pencucian lempeng ELISA dengan pencuci Phospate Buffer Saline yang mengandung tween-20 0,5\% (v/v) (PBS-T) (Botol A) sebanyak 3 kali, lalu dikeringkan (10 menit)

2. Pengambilan hemolimp udang yang akan dideteksi menggunakan syringe $1 \mathrm{cc}$, kemudian dimasukkan sebanyak $50 \mu \mathrm{L}$ ke

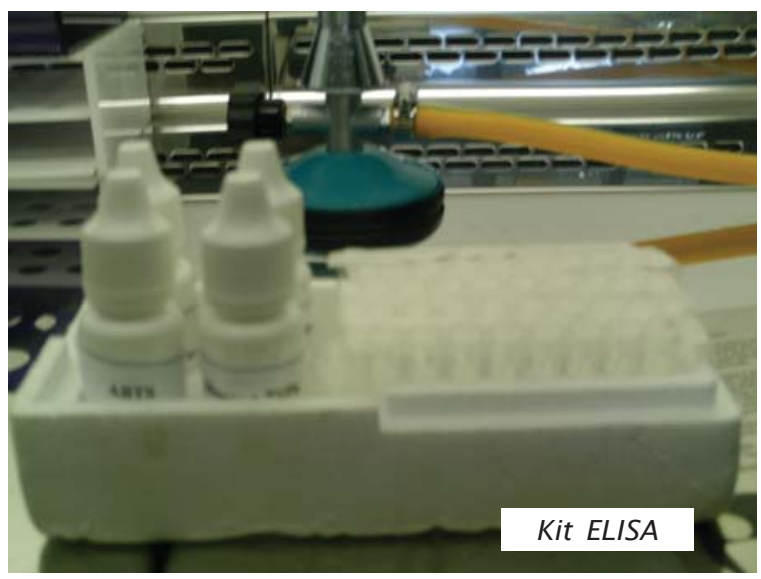

Gambar 2. Kit ELISA WSSV produksi BRPBAP

Figure 2. Kit ELISA WSSV production BRPBAP 
dalam lubang 3 dan 4 untuk sampel pertama dan 5 dan 6 untuk sampel kedua, kemudian dieramkan (inkubasi) 30 menit dalam kondisi yang lembab yaitu dalam lipatan tissue basah (Gambar 3)

3. Lempeng ELISA dicuci dengan Phospate Buffer Saline yang mengandung tween-20 $0,5 \%(\mathrm{v} / \mathrm{v})$ (PBS-T) (Botol A) sebanyak 3 kali, lalu dikeringkan (10 menit)

4. Tiap lubang (8 lubang) diisi sebanyak 50 $\mu \mathrm{L}( \pm 1$ tetes) Mouse $\alpha$ PIPK yang telah diencerkan dengan ELISA diluent $(1: 1000)$ (Botol B), kemudian inkubasi dalam kondisi lembab selama 30 menit

5. Lempeng ELISA dicuci dengan Phospate Buffer Saline yang mengandung tween-20 0,5\% (v/v) (PBS-T) sebanyak 3 kali (Botol A), lalu dikeringkan (10 menit)

6. Tiap lubang (8 lubang) diisi sebanyak 50 $\mu \mathrm{L}( \pm 1$ tetes) Enzim HRPO (Botol C), kemudian inkubasi dalam kondisi lembab selama 30 menit

7. Lempeng ELISA dicuci dengan Phospate Buffer Saline yang mengandung tween-20 $0,5 \%(\mathrm{v} / \mathrm{v})(\mathrm{PBS}-\mathrm{T})$ sebanyak 3 kali (botol A), lalu dikeringkan (10 menit).

8. Sebanyak $100 \mu \mathrm{L}$ (2 tetes) larutan substrat 2,2-Azino-bis(3-ethyl-benzthiazo-line6-sulfonat (ABTS) (Botol D) dimasukkan ke masing-masing lubang dan diinkubasi- kan lagi selama 30 menit dalam kondisi lembab

9. Setelah pemberian substrat, hasil uji ELISA dapat diketahui dengan melihat perubahan warna yang terjadi pada tiap lubang, warna hijau berarti sampel tersebut positif terinfeksi virus WSSV, apabila tidak terjadi perubahan warna artinya negatif (Gambar 4)

Hasil uji lapang menunjukkan Kit ELISA WSSV yang telah diproduksi dapat digunakan di lapangan untuk deteksi penyakit yang disebabkan oleh WSSV. Di Kabupaten Pinrang, dari 6 sampel yang dideteksi 3 di antaranya dinyatakan positif di mana terjadi perubahan warna media dari bening ke hijau, walaupun perubahan warna yang terjadi masih lemah, tetapi, warnanya berbeda dengan kontrol negatif Ketiga sampel yang dinyatakan positif tersebut, secara morfologi terdapat bintik putih pada karapasnya, yang mengindikasikan sampel tersebut terserang WSSV. Di Kabupaten Pangkep, sebanyak 8 sampel yang dideteksi, juga 3 di antaranya terjadi perubahan warna menjadi hijau muda yang mengindikasikan bahwa sampel tersebut positif terinfeksi WSSV.

Dari perhitungan biaya untuk deteksi satu sampel udang ternyata lebih murah (Rp 35.000,-) apabila dibanding dengan biaya deteksi menggunakan PCR (Rp 150.000,-- Rp 300.000,-).

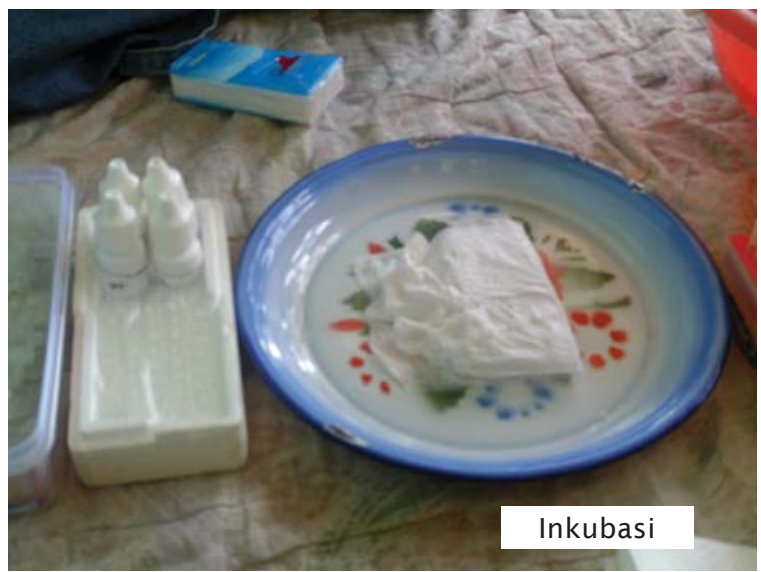

Gambar 3. Inkubasi sampel pada kondisi lembab (dalam lipatan tissue basah) selama 30 menit untuk setiap langkah

Figure 3. Incubation of samples in humid conditions (in the folds of tissue wet) for 30 minutes for each step 


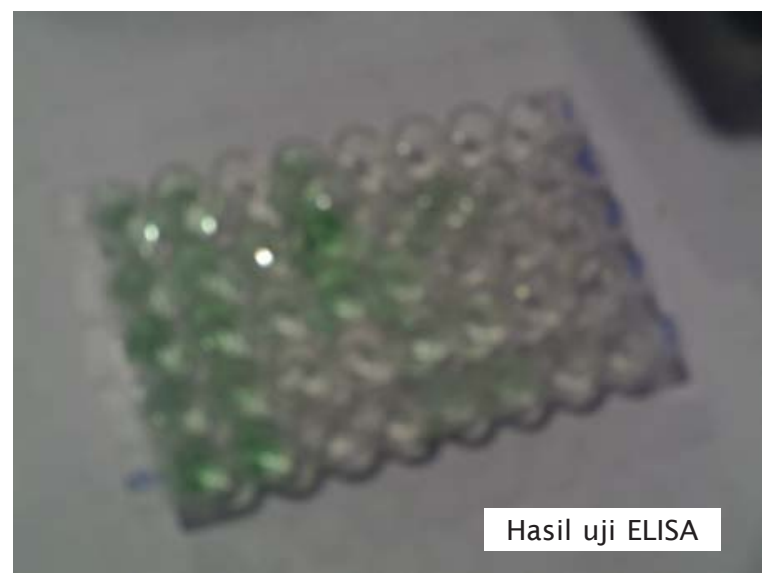

Gambar 4. Hasil akhir dari uji ELISA di Lapangan

Figure 4. The final results of the ELISA test in the field

\section{KESIMPULAN}

Dari hasil uji lapang yang telah dilakukan, disimpulkan bahwa Kit ELISA yang telah dihasilkan dapat digunakan untuk mendeteksi penyakit virus yang disebabkan oleh WSSV pada budidaya udang windu, dengan waktu yang diperlukan \pm 3 jam untuk setiap kali running mulai dari persiapan sampai pembacaan hasil uji.

\section{DAFTAR ACUAN}

Adams, A., Thompson, K.D., Mcewan, H., Chen, S., \& Richard, R.H. 1995. Development of monoclonal antibodies to Mycobacteria sp. Isolated from snake head (Chana striatus) and Siamese figting fish (Betta splenens). J. Aquatic Animal Health. Journal of Fish Diseases, 25(4): 235-243.

Chang, Poh-shing, Hsiao-Chao, C., \& Yu-Chi, W. 1998. Detection of white spot syndrome associated baculovirus in experimentally infected wild shrimp, crab and lobster by in situ hydriztion. Aquaculture, 164: 233242.

De Boer, S.H. \& Schaad, N.W. 1990. Application of monoclonal antibodies. Bacteria. In Hampton, R. and S.H. De Boer (Eds.). Serological Methods for Detection and Identification of Viral and Bacterial Plant Pathogens. A Laboratory Manual. The APS Press, St Paul, Minnesota, p. 79-82.

Gigerli, P. \& Fries, P. 1983. Characterization of monoclonal antibodies to potato virus $Y$ and their use for virus detection. J. Gen. Virol., 64: 2,471-2,477.

Halk, E.L. \& De Boer, S.H. 1985. Monoclonal antibodies in plant disease research. Annu. Rev. Phytopathol, 23: 321-350.

Jordan, R.L. 1990. Strategy and techniques for the production of monoclonal antibodies. In Hampton, R., E. Ball, and S. de Boer (Eds.). Serological Methods for Detection of Viral and Bacterial Plant Pathogens. APS Press, St. Paul, Minn., p. 55-85.

Jordan, R.L. 1990a. Strategy and techniques for the production of monoclonal antibodies:Monoclonal antibody for viruses. In Hampton, R. and S.H. De Boer (Eds.). Serological Methods for Detection and Identification of Viral and Bacterial Plant Pathogens. A Laboratory Manual. The APS Press, St Paul, Minnesota, p. 55-85.

Jordan, R.L. 1990b. Application of monoklonal antibodies, viruses. In Hampton, R. and S.H. De Boer (Eds.). Serological Methods for Detection and Identification of Viral and Bacterial Plant Pathogens. A Laboratory Manual. The APS Press, St Paul, Minnesota, p. 77-78.

Kohler \& Milsten. 1975. Continuous culture of fused cell producing antibodies of predefined specificity. Science, 256: 495497.

Machmud, M., Suryadi, Y., Suhendar, M.A., Harjosudarmo, J., \& Roechan. 1999. Perakitan perangkat ELISA untuk deteksi dan identifikasi Rs, SMV, Psg dan Xcg. 
dengan antibodi poliklonal. Laporan ROPP Tahun Anggaran 1998-1999, UPT Perkebunan, $36 \mathrm{hlm}$.

McLaughlin, R.J. \& Chen, T.A. 1990. ELISA methods for plant pathogenic procaryotes. In Hampton, R. and S.H. De Boer (Eds.). Serological Methods for Detection and Identification of viral and Bacterial Plant Pathogens. A Laboratory Manual. The APS Press, St. Paul, Minnesota, p. 197-201.

Office International des Epizooties (OIE). 1996. Avian Infectious Laryngotracheitis, Manual of standards for diagnostic tests and vaccines, 3rd Ed. OIE, Paris, (723 pp), p. 549-554.

Peng, S.E., Lo, C.F., lin, S.C., Chen, L.L., Chang, Y.S., Liu, K.F., Su, M.S., \& Kou, G.H. 2001. Performance of WSSV- infected and WSSVnegative Penaeus monodon postlarvae in culture ponds. Dis. Aquat.org., 46: 165-172. van Regenmortel, M.H.Vx. 1986. The potential for using monoclonal antibodies in the detection of plant viruses. In Jones, R.A.C. and L. Torrance (Eds.). Development and Application of Virus Tesing. Lavenham Press, Great Britain, p. 89-101. 